\title{
Introduction to the special issue on the Survey of Adult Skills (PIAAC)
}

\author{
Nezih Guner ${ }^{1}$
}

Published online: 2 December 2017

(C) The Author(s) 2017. This article is an open access publication

This special issue brings together five articles on the Survey of Adult Skills (PIAAC). The PIACC measures the proficiency of 16-65 year-olds in literacy, numeracy and problem solving in technology-rich environments. The main motivation for the survey is that these cognitive skills are critical inputs for success in the labor market. There were two rounds of data collection for the PIACC. In the first round, which took place during 2011 and 2012, a total of 166,000 adults between the ages of 16 and 65 were surveyed in 21 countries: Australia, Austria, Belgium (only Flanders), Canada, Cyprus, the Czech Republic, Denmark, England (and separately Northern Ireland), Estonia, Finland, France, Germany, Ireland, Italy, Japan, Korea, the Netherlands, Norway, Poland, Russia, the Slovak Republic, Spain, Sweden and the United States. The second round took place during 2014 and 2015 in 9 additional countries with a total of 50,250 adults. The countries that participated in the second round were Chile, Greece, Indonesia, Israel, Lithuania, New Zealand, Singapore, Slovenia and Turkey. OECD (2016) provides details on the survey and an overview of the key facts.

Table 1 documents the levels of literacy and numeracy proficiency across the OECD countries. The literacy outcomes measure "the ability of individuals to understand, evaluate, use and engagex with written texts in order to participate in society, achieve one's goals, and develop one's knowledge and potential" (OECD 2016, p. 38), while numeracy measures "the ability to access, use, interpret and communicate mathematical information and ideas in order to engage in and manage the mathematical demands of a range of situations in adult life" (OECD 2016, p. 47). The maximum score is 400 in for both measures and the table report average scores for each country. There is a large variation in the average levels of proficiency of literacy and numeracy across

\footnotetext{
Nezih Guner

nezih.guner@cemfi.es

1 CEMFI, Casado del Alisal, 5, 28014 Madrid, Spain
} 


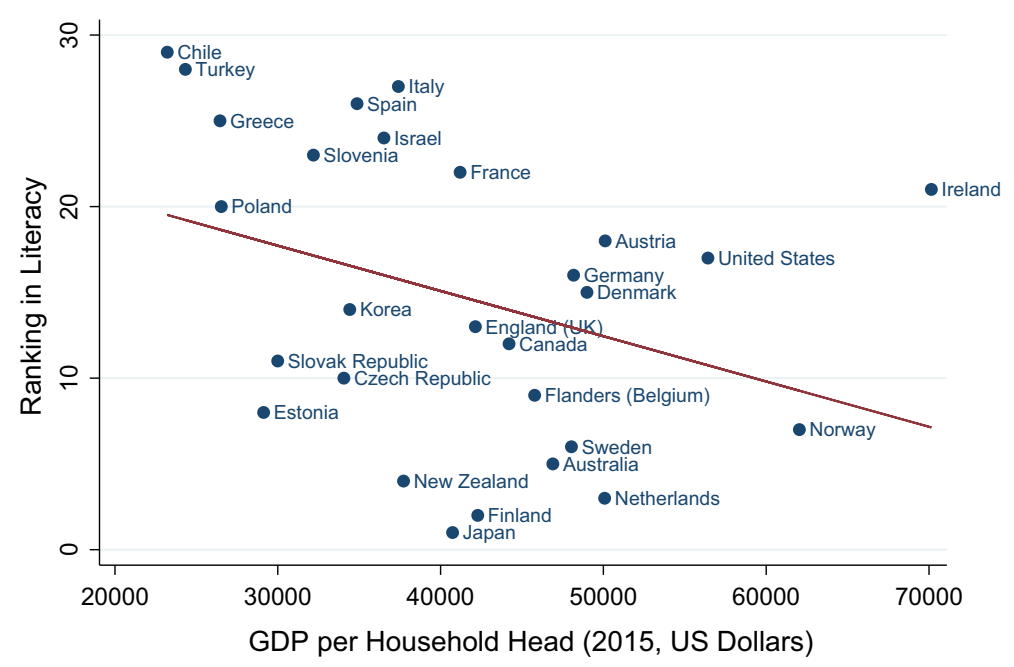

Fig. 1 GDP per capita and literacy ranking

countries. The gap between the country that performs the best (Japan) and the worst (Chile) in literacy is about 97 point or about $28 \%$ of the OECD average for literacy. For the numeracy, the gap between the top and the bottom (again Japan and Chile) is about $31 \%$ of the mean numeracy score. In addition to Turkey and Chile, the poorest OECD members, the Southern European countries, Greece, Italy and Spain perform consistently poorer along both dimensions. Indeed, across the set of countries in Table 1, the two measures are very highly correlated; the correlation coefficient between the two rankings is about $89 \%$.

The last column of Table 1 documents GDP per household head. While there is a negative relationship between the GDP per capita and adult skills, i.e. the richer countries are ranked higher, the relationship is quite far from perfect (the correlation between the GDP per household head and a country's rank in literacy is about - 0.35). Figure 1 provides a cross country plot of the GDP per household head and rankings in literacy. Around 40,000\$, there is a very large variation in skill outcomes, with Japan and Finland doing great and Italy and Spain lagging significantly behind.

What can researchers do with the PIACC survey? An obvious question is whether individuals with better skills, controlling for other observable characteristics, do better in the labor market, in term of earnings and employment opportunities. One can also use the adult skills to build better measures of a country's human capital stock, which goes beyond the measured years of schooling. The PIACC can also help us to understand how different education choices by individuals (vocational or academic) affect their skills as adults. Alternatively, by comparing different cohorts within the PIACC, we can evaluate how education reforms, which might alter the length or the content of formal education, affect adult outcomes. The PIACC can also be used to study whether individuals who receive training in their firms improve their skills, and how labor market institutions, such as labor market duality, affect firms' incentive to train their workers. While Table 1 documents results for the cognitive skills, the PIACC can also 
Table 1 Performance in literacy and numeracy. Source: Columns 2-5, OECD (2016, Figure 1.1.); column 6, http://stats.oecd.org, the level evel of GDP per capita and productivity

\begin{tabular}{|c|c|c|c|c|c|}
\hline Country & Literacy & $\begin{array}{l}\text { Literacy } \\
\text { ranking }\end{array}$ & Numeracy & $\begin{array}{l}\text { Numeracy } \\
\text { ranking }\end{array}$ & $\begin{array}{l}\text { GDP per household } \\
\text { head }(2015)\end{array}$ \\
\hline Australia & 280.40 & 5 & 267.63 & 14 & $46,894.4$ \\
\hline Austria & 269.45 & 18 & 275.04 & 10 & $50,108.9$ \\
\hline Canada & 273.49 & 12 & 265.46 & 15 & $44,205.0$ \\
\hline Chile & 220.15 & 29 & 206.06 & 29 & $23,210.9$ \\
\hline $\begin{array}{l}\text { Czech } \\
\text { Republic }\end{array}$ & 274.01 & 10 & 275.73 & 9 & $34,058.3$ \\
\hline Denmark & 270.79 & 15 & 278.28 & 7 & $48,992.1$ \\
\hline England (UK) & 272.58 & 13 & 261.81 & 17 & $42,136.9$ \\
\hline Estonia & 275.88 & 8 & 273.12 & 11 & $29,130.7$ \\
\hline Finland & 287.55 & 2 & 282.23 & 2 & $42,281.9$ \\
\hline $\begin{array}{l}\text { Flanders } \\
\text { (Belgium) }\end{array}$ & 275.48 & 9 & 280.39 & 3 & $45,776.3$ \\
\hline France & 262.14 & 22 & 254.19 & 22 & $41,199.2$ \\
\hline Germany & 269.81 & 16 & 271.73 & 12 & $48,170.0$ \\
\hline Greece & 253.89 & 25 & 251.86 & 24 & $26,450.0$ \\
\hline Ireland & 266.54 & 21 & 255.59 & 21 & $70,146.4$ \\
\hline Israel & 255.24 & 24 & 251.05 & 25 & $36,519.8$ \\
\hline Italy & 250.48 & 27 & 247.13 & 26 & $37,407.1$ \\
\hline Japan & 296.24 & 1 & 288.17 & 1 & $40,737.3$ \\
\hline Korea & 272.56 & 14 & 263.39 & 16 & $34,421.5$ \\
\hline Netherlands & 284.01 & 3 & 280.35 & 4 & $50,077.6$ \\
\hline New Zealand & 280.67 & 4 & 271.13 & 13 & $37,724.8$ \\
\hline $\begin{array}{l}\text { Northern } \\
\text { Ireland (UK) }\end{array}$ & 268.70 & 19 & 259.17 & 19 & \\
\hline Norway & 278.43 & 7 & 278.30 & 6 & $62,038.2$ \\
\hline Poland & 266.90 & 20 & 259.77 & 18 & $26,529.6$ \\
\hline $\begin{array}{l}\text { Slovak } \\
\text { Republic }\end{array}$ & 273.85 & 11 & 275.81 & 8 & $29,995.3$ \\
\hline Slovenia & 256.39 & 23 & 257.56 & 20 & $32,189.2$ \\
\hline Spain & 251.79 & 26 & 245.82 & 27 & $34,867.4$ \\
\hline Sweden & 279.23 & 6 & 279.05 & 5 & $48,037.8$ \\
\hline Turkey & 226.54 & 28 & 219.43 & 28 & $24,324.2$ \\
\hline United States & 269.81 & 17 & 252.84 & 23 & $56,420.4$ \\
\hline $\begin{array}{l}\text { OECD } \\
\text { average }\end{array}$ & 267.69 & & 263.04 & & $41,199.5$ \\
\hline
\end{tabular}

be used to measure how non-cognitive skills affect earnings, by exploiting information on skipped questions or average time per question on the test. These are among the questions that the papers in this issue try to answer. Answers to these questions are critical for countries, like Spain, that perform poorly on the PIACC, have high levels 
of unemployment and in particular long-term unemployment (Bentolila et al. 2017), suffer from low and stagnant levels of TFP (Diaz and Franjo 2016; Conesa and Kehoe 2017), have dual labor markets in which workers with temporary and permanent contract face very different levels of severance payments (Bentolila et al. 2012), and are characterized by high levels of mismatch or over-education of workers for the tasks they perform (Obiols-Holms and Sanchez-Marcos 2017).

Open Access This article is distributed under the terms of the Creative Commons Attribution 4.0 International License (http://creativecommons.org/licenses/by/4.0/), which permits unrestricted use, distribution, and reproduction in any medium, provided you give appropriate credit to the original author(s) and the source, provide a link to the Creative Commons license, and indicate if changes were made.

\section{References}

Bentolila S, Cahuc P, Dolado JJ, Le Barbanchon T (2012) Two-tier labour markets in the Great Recession: France versus Spain. Econ J 122:F155-F187

Bentolila S, Garcia-Perez JI, Jansen M (2017) Are the Spanish long-term unemployed unemployable? SERIEs J Span Econ Assoc 8:1-41

Conesa JC, Kehoe JT (2017) Productivity, taxes, and hours worked in Spain: 1970-2015. SERIEs J Span Econ Assoc 8:201-223

Diaz A, Franjo L (2016) Capital goods, measured TFP and growth: the case of Spain. Eur Econ Rev 83:19-39

Obiols-Holms F, Sanchez-Marcos V (2017) Education, occupation-mismatch and unemployment. Mimeo, Universitat Autonoma de Barcelona

OECD (2016) Skills matter: further results from the Survey of Adult Skill. OECD skills studies. OECD Publishing, Paris

\section{Publisher's Note}

Springer Nature remains neutral with regard to jurisdictional claims in published maps and institutional affiliations. 